\title{
IN VITRO AND IN SILICO ANTIMICROBIAL STUDY OF STANNANE OF PYRIDOXAL 5- PHOSPHATE
}

\author{
ROHIT BABU ANIYERY1* ${ }^{*}$, ANITA GUPTA²a, PRASHANT SINGH ${ }^{2 b}$, SANJU ${ }^{3}$

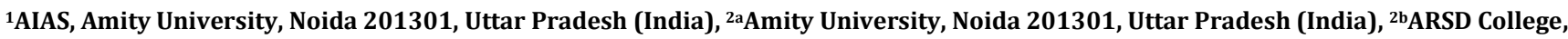 \\ Delhi University, Dhaula Kuan, New Delhi, Delhi 110021, 3AIAS, Amity University, Noida 201301, Uttar Pradesh (India)
}

Email: rohit@zlifeeducation.org

Received: 01 Sep 2016 Revised and Accepted: 21 Dec 2016

\section{ABSTRACT}

Objective: The main objective of this research work is to synthesize a novel stannane of pyridoxal 5-phosphateand to study its antibacterial property.

Methods: Conventional method was used to synthesize the stannane of pyridoxal 5-phosphateand its characterization was carried using UV-visible and ${ }^{1} \mathrm{H}$ NMR. The antibacterial study was carried against, Staphylococcus aureus (gram positive) and Escherichia coli 1610(gram negative) using well diffusion method. In silico antimicrobial was carried out using computational software iGemDock v2.1 tool.(Graphical Drug Design system for Docking, Screening, and Post-analysis), computational docking was carried out using different PDB (Protein Data Bank) files (2I42, 3E00, 3D2U and 3D2Y). The structure was optimized prior docking using Gaussian software, and the method followed was Energy (Ground state) Hartree-Fork.

Results: It was observed that the stannane of pyridoxal 5-phosphateinhibited bacterial growth of Staphylococcus aureus (gram positive) and Escherichia coli 1610 (gram negative) in vitro antibacterial study. The complex has shown good docking results on almost all the receptors, with interaction supporting the fitting of the drug to the target molecules. The novel complex has shown good antibacterial activity (theoretically) in insilico studies. It was found to having a good potency to efficiently inhibit the microbes Burkholderia pseudomallei, Human cytomegalovirus, Yersinia enterocolitica and Escherichia coli, based on the interaction profile. The synthesized stannane was found to be effective in halting the undesirable effects of selected PDB files.

Conclusion: On the basis of the above findings in the present research work, the novel complex was found to be a good antimicrobial agent and our future studies will aim design of novel selective and potent inhibitors. Further in vitro studies of this compound against these bacteria will lead to a new pathway to a novel antibacterial drug discovery.

Keywords: Stannane, Insilco and In vitro antibacterial study, Computational docking, Protein Data Bank files (PDB), Escherichia coli, Yersinia enterocolitica, Burkholderia pseudomallei, Human cytomegalovirus, Staphylococcus aureus

(c) 2017 The Authors. Published by Innovare Academic Sciences Pvt Ltd. This is an open access article under the CC BY license (http://creativecommons.org/licenses/by/4. 0/) DOI: http://dx.doi.org/10.22159/ijpps.2017v9i2.15002

\section{INTRODUCTION}

Stannanes are attaining great interest because of its wide application in biological and potential activity in the area of inorganic and metal organic chemistry. It is utilized widely in industries such as marine anti-biofouling paints, preservatives, fungicides, bactericides, acaricides and fire retardants. Advances in the use of stannane or organotin (IV) compounds in pharmacological as antibacterial, antifungal, anti-tuberculosis and cytotoxic agents $[1,2]$ and better biological action as an anticancer drug as compared to other traditional heavy metals, have gained relevant interest. These complexes are extensively contemplated because of their coordination geometries as well as structural diversity they have (monomeric, dimeric, hexameric, and oligomeric). Tin in +4 coordination forms most stable complexes with a unique structure and physicochemical properties that are used in the synthesis of organic compounds, used as heat stabilizers and catalysts, in drug development as biologically active agents, and in other areas. Physiochemical properties of the organometallic complex are quiet exclusive and now being extensively used in medicinal inorganic chemistry. The results of research work undergone till now are quite impressive, some of the organometallic complexes have already entered clinical trials. Stannanes have gained an edge over other organometallics owing to their bioavailability in ecosystem and entrance into the food chain, the fact they are less dangerous to the environment and their pharmaceutical applications [3]. So by keeping in mind the various applications of stannane/ organotin (IV) complexes and further continuation of our work [4, 5], we here report the synthesis, characterization, in vitro and insilico antimicrobial study of stannane of pyridoxal 5-phosphateto develop a novel broad-spectrum antibacterial agent.

\section{MATERIALS AND METHODS}

\section{Chemicals}

All the experimental works were carried out using analytical grade chemicals and solvents, they were procured from commercial sources; dibutyltin (IV) oxide obtained from spectrochem, benzene from qualigen, ethanol from Spectrochem, dimethyl sulfoxide (DMSO) from Fischer scientific and pyridoxal 5-phosphate from the Ipzah pharmaceuticals industrial area Patiala (Punjab, India) with 99\% purity and was used without undergoing any further purification process. Standard procedure was followed for solvent drying process [6]

\section{Instruments}

The instrument used for the sterilizing purpose in antimicrobial study was Khera laboratory autoclave, Khera instrumentation (pressure range $0-30 \mathrm{lb} /$ in 2 or $0-2.1 \mathrm{~kg} / \mathrm{cm}^{2}$ ) and incubator used was an orbital shaker, PSN instrumentation Pvt Ltd. The UV (Ultraviolet) visible spectra study was carried using UV instrument SHIMADZU UV 1800, at wavelength $200-600 \mathrm{~nm}$ in ethanol medium. The ${ }^{1} \mathrm{H}$ NMR (nuclear magnetic resonance)spectra was recorded using DMSO-d 6 solution, TMS (tetramethylsilane) as internal standard)at $25{ }^{\circ} \mathrm{C}$ on a JEOL ECX-400P NMR spectrophotometer at $400 \mathrm{MHz}$ and $100 \mathrm{MHz}$. NMR spectra was processed using software JEOL Delta ${ }^{\mathrm{TM}}$.

\section{Experimental method}

The synthesis was carried out using the conventional method that is azeotropic distillation method [7]. Benzene $(30 \mathrm{ml})$ along with 
absolute ethanol $(10 \mathrm{ml})$ and dibutyltin (IV) oxide $(1 \mathrm{mmol})$ were added in a round bottom flask. Then $2 \mathrm{mmol}$ of ligand (pyridoxal 5 phosphate) was added into the mixture and maintained the metal: ligand molar ratio to be $1: 2$. The entire reaction mixture was then refluxed for 15 min azeotropically, in a dean stark separator. The process of refluxing was further continued for $6 \mathrm{~h}$ till there was complete removal of water from the reaction mixture. Excess of solvent left was then removed using a rotator evaporator. The final product obtained was characterized by UV-visible spectra studies and ${ }^{1} \mathrm{H}$ NMR spectra.
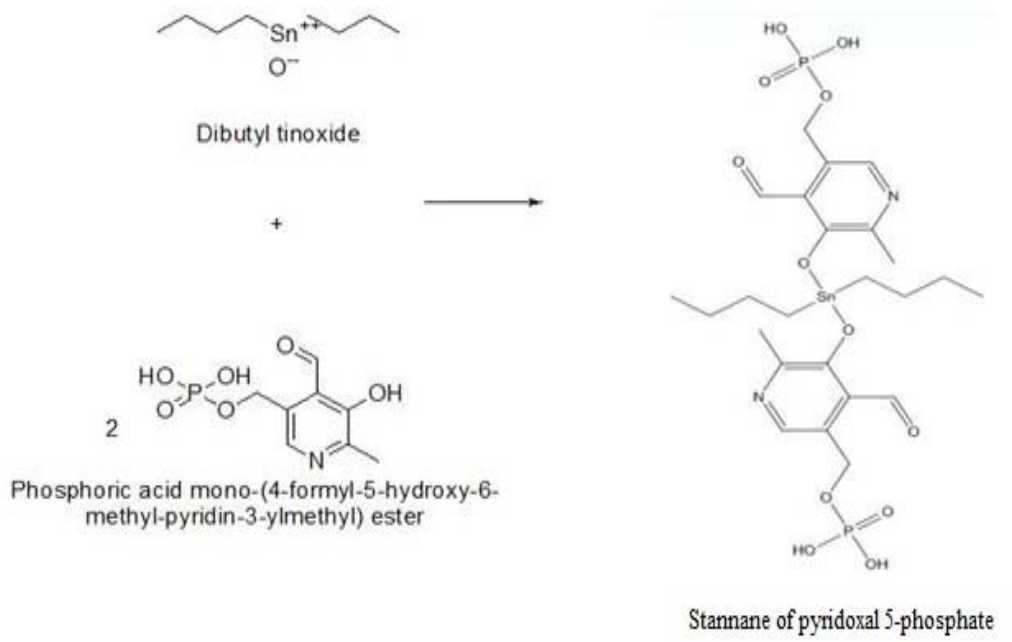

Fig. 1: Synthesis of stannane of pyridoxal 5-phosphate

\section{In vitro antibacterial test}

The ligand pyridoxal 5-phosphateand its synthesized stannane were screened in vitro for their antibacterial activity using the agar well diffusion method [4]. Staphylococcus aureus (gram-positive) and Escherichia coli1610 (gram-negative) bacterial strains were cultivated separately in nutrient agar plates. The $250 \mathrm{ml}$ bacterial inoculums (0.168 OD (optical density)) was prepared and incubated in an incubator for $24 \mathrm{~h}$. The wells were dug $(6 \mathrm{~mm})$ in the nutrient agar media using a sterile metallic borer. Using sterile cotton swabs the prepared 24-hour bacterial inoculums were spread over the surface of the nutrient agar. The ligand and its organotin (IV) complex sample having the concentration of $0.02 \mathrm{~g} / 100 \mathrm{ml}$ in ethanol were introduced into the respective wells using micropipettes. Other wells having distilled water and the reference antibacterial drug, i.e. chloramphenicol served as negative and positive controls respectively. Further samples of stannane of pyridoxal 5-phosphatewith different concentrations $(0.001 \mathrm{~g} / 100 \mathrm{ml}, 0.0005 \mathrm{~g} / 100 \mathrm{ml}, 0.00025 \mathrm{~g} / 100 \mathrm{ml}$ and $0.000125 \mathrm{~g} / 100 \mathrm{ml}$ in ethanol) were introduced into different wells. The plates were then incubated immediately at $37^{\circ} \mathrm{Cfor} 24 \mathrm{~h}[8$, 6]. Inhibition zone was measured in $\mathrm{mm}$, to determine the antibacterial activity. The observed results were further compared with the control (chloramphenicol) and also the minimum inhibition concentration (MIC) was also determined after $24 \mathrm{~h}$ of incubation [9]. The lowest concentration of stannane that inhibited the visible growth of the bacterial strains were recorded as the MIC value.

\section{Determination of the percentage inhibition of diameter growth (PIDG)}

The data on the growth responses of the bacterial strains to various concentrations of the stannane following a 24-hour incubation period were analyzed, using the percentage inhibition of diameter growth (PIDG) against chloramphenicol. The percentage inhibition of diameter growth (PIDG) values was determined according to the equation as below [10]:

$$
\text { PIDG (\%) }=\frac{\text { Diameter of sample }- \text { Diameter of Control }}{\text { Diameter of Control }} \times 100
$$

\section{In silico antimicrobial studies using molecular docking software (IGEMDOCK)}

Numerous docking software is accessible but we have worked just on iGEMDOCK, a structure-based virtual screening framework. It is an in-house docking tool with features from preparations through to post-screening analysis. It gives a related interface to construct both the binding site of the target protein and the screening compound library. iGemDock v2.1software gives protein interaction profiles of vander Waal's (V) interactions, electrostatic (E) and hydrogenbonding. It ranks and forms a concept of the screening compounds by the combination of the energy-based scoring function and pharmacological interactions. The empirical scoring function of iGemdock was calculated using the formula:

$$
\text { Energy }=\mathrm{vdW}+\text { Hbond }+ \text { Elec } \text {. }
$$

Here, the vdW refers to van der Waal energy; Hbond refers to hydrogen bonding energy and Elect refer to electro statistic energy. This software is helpful in the structure-based virtual screening and post-screening analysis for the drug discovery. The software is maintained by Drug Design and Systems Biology Laboratory of National Chiao Tung University, Taiwan. The precision of molecular docking and the screening utility were better than other docking methods. These results have been published [11,12].

\section{Preparation of binding site}

A literature survey was done for the selection of Binding site. All the protein structure files for docking were downloaded from Protein Data Bank (http://www. rcsb. org/) (PDB ID: 2I42, 3E00, 3D2U, and 3D2Y).

\section{Ligand preparation and docking}

The structure of stannane ofpyridoxal 5-phosphate was drawn using Chem Draw software. The structure was optimized prior docking using Gaussian software, and the method followed was Energy (Ground state) Hartree-Fork. iGemDock v2.1software mainly accepts files in MDL(3D Design Plus Geometrical Model), MOL/MOL 2 (molecular file), SLN (SYBYL line notation) and PDB format. Therefore the ligand file in CDX (compound index) format was converted into MOL 2 format by Openbabel software [13]. Docking with each PDB files was done using accurate docking function (slow docking) [12]. Lastly, the post analysis tool which works by using Kmeans visualized and ranked the screening compound by conglomerating the pharmacological interactions and energy-based scoring function. Step-wise energy optimization was done in this work by first hydrogen, second side chains and finally the backbone of the receptor $[14,15]$. After that, the optimized complexes were then checked for various interaction of ligand with receptor like hydrogen bonding, hydrophobic bonding and van der Waal's interaction. 


\section{RESULTS AND DISCUSSION}

\section{Physical study}

Stannane of pyridoxal 5-phosphatewas obtained in a good yield and the reported yield was $78 \%$, a light brown/sienna coloured solid, soluble in DMSO and ethanol. Elemental analysis calculated was found to be; carbon: $39.75 \%$; hydrogen: $5.00 \%$; nitrogen: $3.86 \%$; oxygen: $26.47 \%$; phosphorus: $8.54 \%$ and tin: $16.37 \%$.

\section{Characterization}

\section{UV Spectral studies}

The peaks of pyridoxal 5-phosphate were reported at $\lambda_{\max } 204.00 \mathrm{~nm}$ (absorbance, 0.016815 ) which is assigned to $\pi-\pi^{*}$ transition. The peaks of the product obtained that is stannane of pyridoxal 5phosphate was reported at $\lambda_{\max } 259.00 \mathrm{~nm}$ (absorbance 0.19531) and $\lambda_{\max } 292.00$ (absorbance 2.091965) which is assigned to $\mathrm{n}-\boldsymbol{\pi}^{*}$ transition. This shifting of absorption maxima to longer wavelength, known as "Bathochromic shift or Redshift" is due to the presence of non-bonding electron pair as they become available for interaction with the metal ion. This gave the evidence of complex formation as this confirmed the coordination of ligand pyridoxal 5-phosphate to the dibutyltin (IV) oxide (Ligand-Metal Charge Transfer (LCMT)) [16]. On further dilution of stannane samples, peaks were reported as

1. Dilution $1(0.002 \mathrm{~g} / 100 \mathrm{ml}): \lambda_{\max } 259.00$ (absorbance 0.171570$)$ and 290.00(absorbance 1.848114);
2. Dilution $2(0.001 \mathrm{~g} / 100 \mathrm{ml}): \lambda_{\max } 259.00$ (absorbance 0.171570 and 290.00(absorbance 0.729538).

3. Dilution $3(0.0005 \mathrm{~g} / 100 \mathrm{ml}): \lambda_{\max } 259.00$ (absorbance 0.070618 ) and 290.00(absorbance 0.297668).

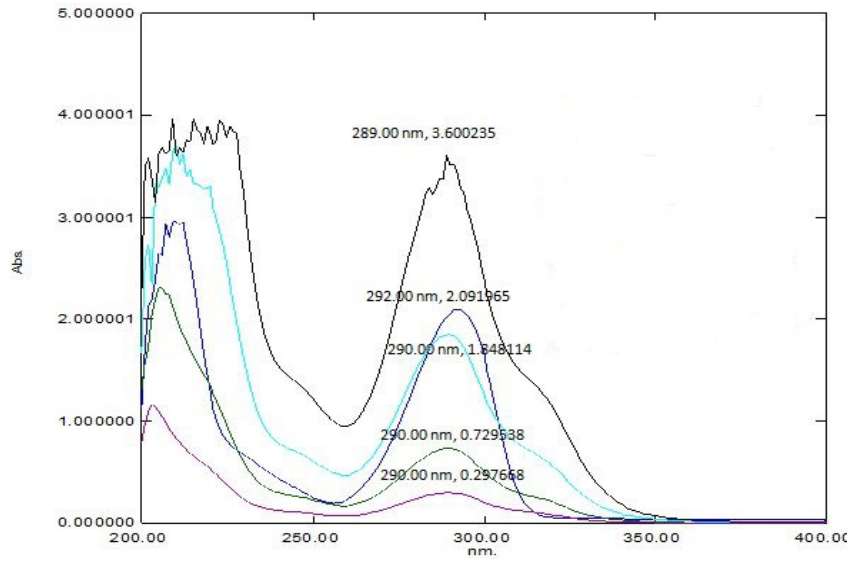

Fig. 2: UV overlay graph of pyridoxal 5-phosphate and stannane of pyridoxal 5-phosphate

Table 1: Physical data for ligand and its stannane

\begin{tabular}{|c|c|c|c|c|c|}
\hline Compound & $\begin{array}{l}\text { Molecular } \\
\text { Formula }\end{array}$ & $\begin{array}{l}\text { Molecular } \\
\text { weight }\end{array}$ & Colour & $\begin{array}{l}\text { Yield } \\
(\%)\end{array}$ & Solubility \\
\hline $\begin{array}{l}\text { Pyridoxal 5- } \\
\text { phosphate }\end{array}$ & $\mathrm{C}_{8} \mathrm{H}_{10} \mathrm{NO}_{6} \mathrm{P}$ & 247.142 & $\begin{array}{l}\text { Pale yellowish white crystalline } \\
\text { powder }\end{array}$ & - & $\begin{array}{l}\text { alkaline solutions; sparingly soluble } \\
\text { in water }\end{array}$ \\
\hline $\begin{array}{l}\text { Stannane of } \\
\text { pyridoxal 5- } \\
\text { phosphate }\end{array}$ & $\mathrm{C}_{24} \mathrm{H}_{36} \mathrm{~N}_{2} \mathrm{O}_{12} \mathrm{P}_{2} \mathrm{Sn}$ & 725.213 & $\begin{array}{l}\text { Light } \\
\text { brown/sienna }\end{array}$ & 78 & soluble in DMSO and ethanol \\
\hline
\end{tabular}

Table 2: UV data for ligand pyridoxal 5-phosphate and stannane of pyridoxal 5-phosphate

\begin{tabular}{lll}
\hline Sample & Wavelength (nm) & Absorbance \\
\hline Ligand(pyridoxal 5-phosphate) & 204.00 & 0.016815 \\
& 256.00 & 0.946762 \\
Stannane of pyridoxal 5-phosphate & 292.00 & 2.091965 \\
& 259.00 & 0.19531 \\
Stannane of pyridoxal 5-phosphate (dilution 1) & 290.00 & 1.848114 \\
& 259.00 & 0.171570 \\
Stannane of pyridoxal 5-phosphate & 290.00 & 0.729538 \\
(dilution 2) & 259.00 & 0.171570 \\
Stannane of pyridoxal 5-phosphate (dilution 3) & 290.00 & 0.297668 \\
& 259.00 & 0.070618 \\
\hline
\end{tabular}

(*Dilution 1-(0.002 g/100 ml), dilution 2-(0.001 g/100 ml), dilution 3- $(0.0005 \mathrm{~g} / 100 \mathrm{ml})$

\section{${ }^{1} \mathrm{H}$ NMR}

Table 3: ${ }^{1} \mathrm{H}$ NMR spectral data $(\delta, \mathrm{ppm})$ of stannane of pyridoxal 5-phosphate

\begin{tabular}{ll}
\hline Groups & Chemical shift (ppm) \\
\hline$-\mathrm{OH}$ of phosphate group(dihydrogen phosphate) & 11.98 \\
$-\mathrm{CH}$,attached to formyl/aldehyde group & 9.73 \\
- $\mathrm{CH}$ of 2-pyridine group & 8.77 \\
$-\mathrm{CH}_{2}$ (methylene) attached to oxygen atom of phosphate group & 5.29 \\
$\mathrm{CH}_{3}$,methyl group attached at 6 positions of pyridine ring & 2.53 \\
Methylene- $\mathrm{CH}_{2}$ of n-butyl group & $1.57,1.27$ \\
Methyl- $\mathrm{CH}_{3}$ of n-butyl group & 0.91 \\
\hline
\end{tabular}


Table 4: Diameter of inhibition zone and its interpretation for bacterial Strain-Escherichiacoli

\begin{tabular}{|c|c|c|c|c|}
\hline S. No. & Sample & $\begin{array}{l}\text { Inhibition } \\
\text { zone (mm) }\end{array}$ & Interpretation & $\begin{array}{l}\text { PIDG } \\
(\%)\end{array}$ \\
\hline 1 & Control-Chloramphenicol & $19.5 \pm 1.5$ & $\begin{array}{l}\text { Inhibition zone greater than } 16 \mathrm{~mm} \text { hence it is an active } \\
\text { antimicrobial agent }\end{array}$ & 100 \\
\hline 2 & Pyridoxal 5-phosphate & - & Nil/No antimicrobial activity & - \\
\hline 3 & $\begin{array}{l}\text { Stannane of Pyridoxal 5-phosphate }(0.002 \\
\mathrm{g} / 100 \mathrm{ml})\end{array}$ & $13.7 \pm 1.3$ & $\begin{array}{l}\text { Inhibition zone greater than } 10 \mathrm{~mm} \text { but less than } 16 \mathrm{~mm} \text {, } \\
\text { hence it is a moderate antimicrobial agent }\end{array}$ & -28.57 \\
\hline 4 & $\begin{array}{l}\text { Stannane of Pyridoxal 5-phosphate } \\
\text { Dilution }(0.001 \mathrm{~g} / 100 \mathrm{ml})\end{array}$ & $9.6 \pm 0.5$ & $\begin{array}{l}\text { Inhibition zone greater than } 10 \mathrm{~mm} \text { but less than } 16 \mathrm{~mm} \text {, } \\
\text { hence it is a moderate antimicrobial agent }\end{array}$ & -52.38 \\
\hline 5 & $\begin{array}{l}\text { Stannane of Pyridoxal 5-phosphate } \\
\text { Dilution }(0.0005 \mathrm{~g} / 100 \mathrm{ml})\end{array}$ & - & Nil/No antimicrobial activity & - \\
\hline 6 & $\begin{array}{l}\text { Stannane of Pyridoxal 5-phosphate } \\
\text { Dilution }(0.00025 \mathrm{~g} / 100 \mathrm{ml})\end{array}$ & - & Nil/No antimicrobial activity & - \\
\hline 7 & $\begin{array}{l}\text { Stannane of Pyridoxal 5-phosphate } \\
\text { Dilution }(0.000125 \mathrm{~g} / 100 \mathrm{ml})\end{array}$ & - & Nil/No antimicrobial activity & - \\
\hline
\end{tabular}

No activity

Table 5: Diameter of inhibition zone and its interpretation for bacterial strain-Staphylococcus aureus

\begin{tabular}{|c|c|c|c|c|}
\hline S. No. & Sample & $\begin{array}{l}\text { Inhibition zone } \\
\text { (mm) }\end{array}$ & Interpretation & $\begin{array}{l}\text { PIDG } \\
(\%)\end{array}$ \\
\hline 1 & $\begin{array}{l}\text { Control- } \\
\text { Chloramphenicol }\end{array}$ & $14.2 \pm 1.8$ & $\begin{array}{l}\text { Inhibition zone greater than } 16 \mathrm{~mm} \text { hence it is an active } \\
\text { antimicrobial agent }\end{array}$ & 100 \\
\hline 2 & Pyridoxal phosphate & - & No activity & - \\
\hline 3 & $\begin{array}{l}\text { Stannane of pyridoxal 5-phosphate } \\
\text { Dilution }(0.002 \mathrm{~g} / 100 \mathrm{ml})\end{array}$ & $12.6 \pm 1.4$ & $\begin{array}{l}\text { Inhibition zone greater than } 10 \mathrm{~mm} \text { but less than } 16 \\
\mathrm{~mm} \text {, hence it is a moderate antimicrobial agent }\end{array}$ & -12.5 \\
\hline 4 & $\begin{array}{l}\text { Stannane of pyridoxal 5-phosphate } \\
\text { Dilution }(0.001 \mathrm{~g} / 100 \mathrm{ml})\end{array}$ & $7.3 \pm 0.7$ & Moderate, & -50 \\
\hline 5 & $\begin{array}{l}\text { Stannane of pyridoxal 5-phosphate } \\
\text { Dilution }(0.0005 \mathrm{~g} / 100 \mathrm{ml})\end{array}$ & - & Nil/No antimicrobial activity & - \\
\hline 6 & $\begin{array}{l}\text { Stannane of pyridoxal 5-phosphate } \\
\text { Dilution }(0.00025 \mathrm{~g} / 100 \mathrm{ml})\end{array}$ & - & Nil/No antimicrobial activity & - \\
\hline 7 & $\begin{array}{l}\text { Stannane of pyridoxal 5-phosphate } \\
\text { Dilution }(0.000125 \mathrm{~g} / 100 \mathrm{ml})\end{array}$ & - & Nil/No antimicrobial activity & - \\
\hline
\end{tabular}

No activity

Table 6: Minimum inhibition concentrations (MIC*)

\begin{tabular}{lll}
\hline Bacterial strain & Sample concentration $(\mathbf{g} / \mathbf{1 0 0} \mathbf{~ m l})$ & ppm \\
\hline Escherichia coli1610 & 0.001 \\
Staphylococcus aureus & 0.001 \\
\hline
\end{tabular}

*MIC refers to the lowest conc. of antibacterial agent required to inhibit the visible growth of microbes

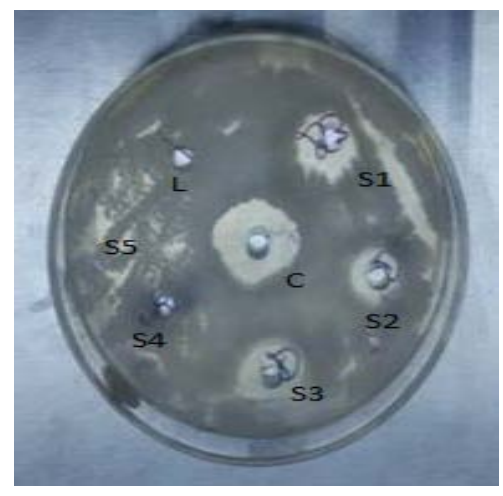

Fig. 3a: Developed plate of Staphylococcus aureus loaded with ligand (pyridoxl 5-phosphate) and stannane of pyridoxl 5-phosphate

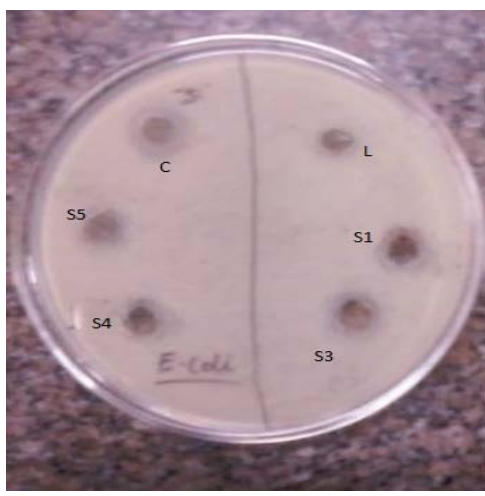

Fig. 3b: Developed plate of Escherichia coli 1610 loaded with ligand (pyridoxl 5-phosphate) and stannane of pyridoxal 5-phosphate

C-Chloramphenicol; L-ligand(pyridoxal 5-phosphate);S1-stannane of pyridoxal 5-phosphate, dilution 1 (0.002 g/100 ml);S2-stannane of pyridoxal 5-phosphate,dilution $2(0.001 \mathrm{~g} / 100 \mathrm{ml}) ; \mathrm{S} 3$-stannane of pyridoxal 5-phosphate, dilution $3(0.0005 \mathrm{~g} / 100 \mathrm{ml}) ; \mathrm{S} 4$-stannane of pyridoxal 5-phosphate dilution 4(0.00025g/100 ml);S5-stannane of pyridoxal 5-phosphate,dilution $5(0.000125 \mathrm{~g} / 100 \mathrm{ml}$.

The data on the growth responses of the bacterial strains to various concentrations of the stannane following a 24-hour incubation period were analysed, using the percentage inhibition of diameter growth (PIDG) against chloramphenicol. PIDG was calculated by 
taking standard chloramphenicol as the positive control with $100 \%$ inhibition. The synthesized complex has shown PIDG values for different concentration against Escherichia coli 1610 as follows$28.57 \%$ (0.002 g/100 ml),-52.38 \% (0.001 g/100 ml) and-12.5\% $(0.002 \mathrm{~g} / 100 \mathrm{ml}),-50 \%(0.001 \mathrm{~g} / 100 \mathrm{ml})$, against Staphylococcus aureus. Here the negative sign indicates the percentage reduction in antibacterial activity compared with chloramphenicol, taken as $100 \%$ inhibition. The lowest concentration of stannane of pyridoxal 5-phosphate that inhibited the visible growth of the bacterial strain was recorded as the MIC value.

The complex has shown moderate antimicrobial activity against Staphylococcus aureus (gram-positive) and Escherichia coli 1610 (gram-negative) bacteria strains with minimum inhibition concentration reported to be $10 \mathrm{ppm}$ or $0.001 \mathrm{~g} / 100 \mathrm{ml}$. The antimicrobial activity of the synthesised compounds may be due to the presence of a functional pharmacophore, which maximises the lipophilic character of the molecules and eases its movement across the cell membrane of the microorganism [17]. From the observation, it has been assumed that the generation of a specific enzyme which needs free sulfhydryl groups (-SH) for their cellular activity was especially liable to deactivation by ions of the complex [18]. Due to which the organisms were less able to metabolise nutrient and, consequently their growth hindered. The toxicity of metal complexes can be explained as follows: i) the effect of metal ions on the normal cell process, ii) metal ions polarity are seriously decreased on chelation due to the partial distribution of its positive charge with a donor groups and iii) $\pi$-electron delocalization over the entire molecule increases the lipophilic character of the metal complex which results to break down of permeability barrier of the cells and thus its interference with normal cell process [19]. This is further responsible for raising the hydrophobic character and liposolubility of the molecule in traverse cell membrane of the microorganism and thus increases the biological utilisation ratio and activity of the testing drug/compound. Better activities of the metal complexes could likewise be perceived in terms of chelation theory [20], which explains that a decrease in polarizability of the metal could intensify the lipophilicity of the complexes [21].

\section{In silico antimicrobial studies using molecular docking software (iGEMDOCK)}

iGEMDOCK is a tool which can cause which can permit a superior and starting point for reasoning pharmacological interaction which further results in recognizing another novel and potentially active compounds for a particular protein, responsible for causing diseases. Binding energy is released when a drug molecule associates with a target, which leads to overall energy lowering of the complex. Thus, greater the energy released on the binding of a ligand to the protein, greater will be the susceptibility of the ligand to associate with that protein that is it supports the fitting of the drug to the target molecules. The negative value of binding energy change $(\Delta G)$ reveals that the binding process is spontaneous it can fit well in the receptor cavity forming most stable drug receptor energetically [22]. Larger the negative value of binding energy, greater the chemical be accepted as a drug [12].

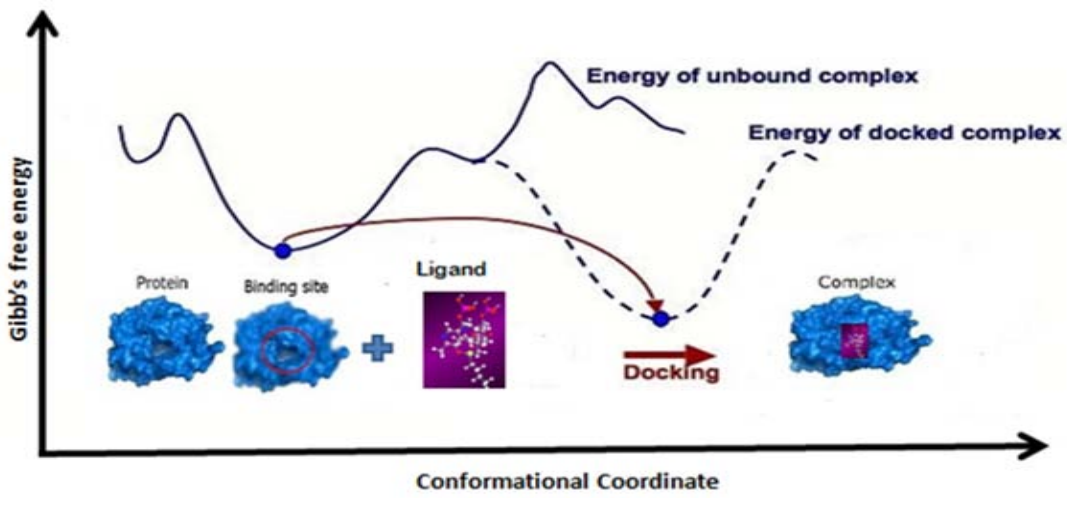

Fig. 4: Interaction of protein's binding site with ligand showing negative value of binding energy change $(\Delta G)$

Table 7: Summary of total energy, vander-waal interaction, hydrogen bonding, and electrostatic energy of stannane of pyridoxal 5 phosphate on interaction with different PDB files

\begin{tabular}{lllll}
\hline PDB File & $\begin{array}{l}\text { Total energy } \\
\text { (kcal/mol) }\end{array}$ & $\begin{array}{l}\text { VDW } \\
\text { (kcal/mol) }\end{array}$ & $\begin{array}{l}\text { Hydrogen bond } \\
\text { (kcal/mol) }\end{array}$ & $\begin{array}{l}\text { Electrostatic } \\
\text { (kcal/mol) }\end{array}$ \\
\hline 3D2U & -84.4068 & -58.4 & -26.9099 & 0.90341 \\
3D2Y & -87.8683 & -68.781 & -25.7585 & 6.67073 \\
3EO0 & -76.9372 & -56.226 & -22.3972 & 1.68596 \\
2I42 & -84.9563 & -70.685 & -14.2711 & 0 \\
\hline
\end{tabular}

PDB 3D2Y is a Protein Data Bank file for Complex of the N-acetylmuramyl-L-alanine amidase AmiD from E. coli with the substrate anhydrous-N-acetylmuramic acid-L-Ala-D-gamma-Glu-L-Lys

\begin{tabular}{lc}
\hline PDB 3D2Y & Energy \\
\hline $\begin{array}{l}\text { Amino acid residue } \\
\text { (predicted pharmacologic interactions) }\end{array}$ & (kcal/mol) \\
\hline H-M-ALA-2 & -10.0129 \\
V-M-TRP-110 & -1.87937 \\
V-S-TRP-110 & -13.0386 \\
V-M-LYS-159 & -5.71715 \\
V-S-LYS-159 & -9.01971 \\
V-S-ASP-160 & -4.8613 \\
\hline
\end{tabular}




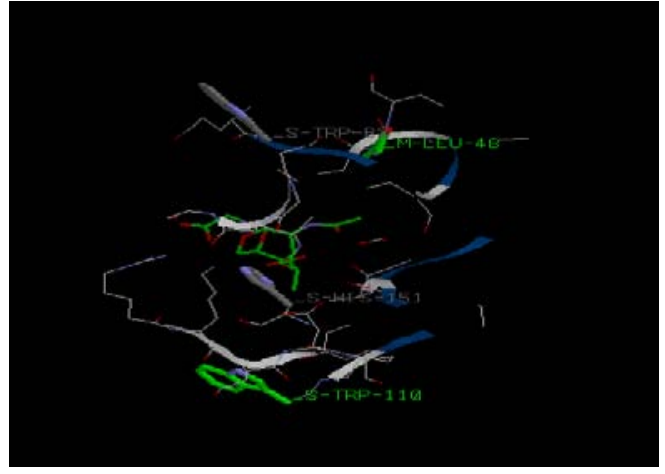

Fig. 5: Docking pose of stannane of pyridoxal 5-phosphatewith PDB 3D2Y

The green and grey color represent the amino acids involved in $(\mathrm{H})$ hydrogen bonding and(V) van der Waals are interaction types $\mathrm{M}$ and $\mathrm{S}$ are main chain and a side chain.

Abbreviations: ALA-alanine; LYS-lysine; TRP-tryptophan; ASPaspartic acid.

\section{Interaction profile}

The stannane of pyridoxal 5-phosphate interacted with the PDB 3D2Yfile with total fitness value of-87.8683 kcal/mol which comprises of-68.781 van der Waal interaction,-25.7585 kcal/mol hydrogen bonding and $6.67073 \mathrm{kcal} / \mathrm{mol}$ electrostatic interaction.
The inhibitor snugly fits the active site cavity making various close contacts with the residues including hydrogen bonding with the main chain of alanine at position 2 with binding energy value$10.0129 \mathrm{kcal} / \mathrm{mol}$. van der Waal interaction was observed with the main chain of tryptophan at position 110 , lysine at position 159 with binding energy value-1.87937 $\mathrm{kcal} / \mathrm{mol}$ and-5.71715 kcal/mol Vander Waal interaction with the side chain of lysine at position 159 , aspartate at position 160, tryptophan at position 110 with binding energy value-9.01971 kcal/mol,-4.8613 kcal/mol and$13.0386 \mathrm{kcal} / \mathrm{mol}$ within the active site of the protein and significant binding interactions have well been noticed from the above fig.

The stannane easily binds to protein structure which plays an important role in hydrolyzing the link between $\mathrm{N}$-acetylmuramoyl residues and L-amino acid residues in certain cell-wall glycopeptides. This protein functions or helps in bacterial cell wall organisation, peptidoglycan turnover and also peptidoglycan catabolic process; hence the entire activity of the protein could be hindered if the complex interacts with this protein [24]. The complex binds with protein pocket which have the most favourable binding energy thus have the potency to inhibit the growth of Escherichia coli. The peptidoglycan is an important part of the cell wall that provides the shape to bacterial cells and assures them against high internal osmotic pressures. It consists of glycan chains having alternating units of $N$-acetylglucosamine (GlcNAc) and $N$ acetylmuramic acid (MurNAc) that are interconnected by covalent cross-links between short peptides. There are mainly four $\mathrm{N}$ acetylmuramoyl-l-alanine amidases in Escherichia coli, namely Ami A,-B,-C, and-D and are located in the periplasm of the cell. AmiA,-B, and-C are soluble enzymes, whereas AmiD is a lipoprotein which is attached to the outer membrane [23].

PDB 3D2U is basically the Protein Data Bank file for structure of UL18, a peptide-binding viral MHC(Major Histocompatibility Complex) mimic, bound to a host Inhibitory receptor, gene names: H301, Glycoprotein UL18

\begin{tabular}{lc}
\hline PDB 3D2U & Energy \\
\hline $\begin{array}{l}\text { Amino acid residue } \\
\text { (predicted pharmacologic interactions) }\end{array}$ & (kcal/mol) \\
\hline H-S-ASN-54 & -6.89036 \\
H-S-NAG-811 & -7.36417 \\
H-M-FUC-814 & -6.17995 \\
V-S-ASN-54 & -10.1667 \\
V-M-GLY-18 & -6.63174 \\
V-S-LYS-19 & -4.02637 \\
V-M-NAG-811 & -2.74136 \\
V-S-NAG-811 & -8.23655 \\
V-M-FUC-814 & -2.41231 \\
\hline
\end{tabular}

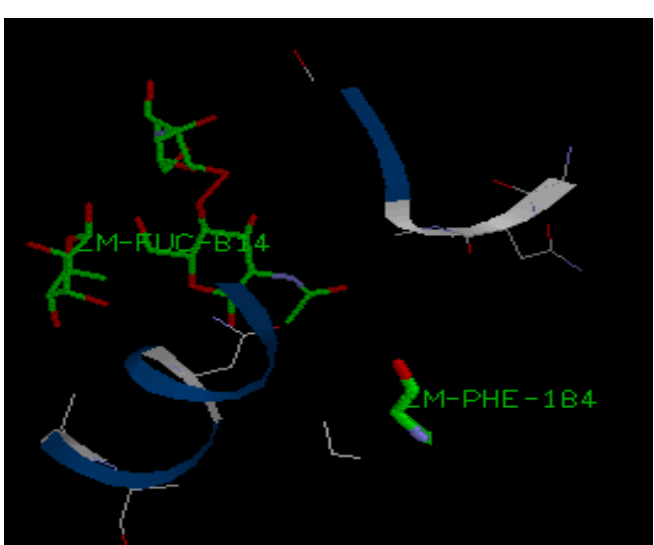

Fig. 6: Docking pose of stannane of pyridoxal 5-phosphatewith PDB 3D2U

The green and grey colour represent the amino acids involved in(H)hydrogen bonding and(V) van der Waals are interaction types $\mathrm{M}$ and $\mathrm{S}$ are main chain and a side chain.
Abbreviations: ASN-asparagine; NAG-N-Acetyl-Glucosamine; LYSlysine; GLY-glycine; FUC-fucose

\section{Interaction profile}

From the results of docking, the stannane of pyridoxal 5phosphatewas found to fit well with the binding sites of the target protein. The complex interacted with the PDB with total fitness value of-84.4068 $\mathrm{kcal} / \mathrm{mol}$ which comprises-58.4 $\mathrm{kcal} / \mathrm{mol}$ van der Waal interaction,-26.9099 kcal/mol, hydrogen bonding and 0.90341 $\mathrm{kcal} / \mathrm{mol}$ electrostatic interaction From fig. 6 it was found that the stannane interacted with basic amino acid,hydrogen bonding with the side chain of asparagine at position 54, N-Acetyl-Glucosamine at position 811 with binding energy value- $10.1667 \mathrm{kcal} / \mathrm{mol}$ and$8.23655 \mathrm{kcal} / \mathrm{mol}$. Vander Waal interaction with the main chain of glycine at position 18 , N-Acetyl-Glucosamine at position 811 , fucose at position814with binding energy value- $6.63174 \mathrm{kcal} / \mathrm{mol},-2.74136$ $\mathrm{kcal} / \mathrm{mol}$ and-2.41231 $\mathrm{kcal} / \mathrm{mol}$ respectively. Van der Waal interaction was observed with the side chain of asparagine at position 54,lysine at position $19, \mathrm{~N}$-Acetyl-Glucosamine at position 811 with binding energy value $-10.1667 \mathrm{kcal} / \mathrm{mol},-4.02637 \mathrm{kcal} / \mathrm{mol}$ and-8.23655 $\mathrm{kcal} / \mathrm{mol}$ respectively.

The study reports that the compounds having highest binding energy are very effective in halting the undesirable effects of 
selected PDB which has biological process like antigen processing and presentation of peptide antigen by MHC class I; immune response of bacteria, negative regulation of interferon-gamma production and biochemical function of glycoprotein binding (interacting selectively and non-covalently with a glycoprotein)[25]. This complex binds with the protein pocket which has the most favourable binding energy and thus it could hinder the protein activity. The complex has the potency to inhibit the Human Cytomegalovirus' glycoprotein UL18 efficiently. Human cytomegalovirus or herpes viruses, express glycoproteinUL18 which is essentially an intensely glycosylated transmembrane bestowing $\approx 25 \%$ sequence identity with class I MHC molecules [26] and helps to prevent host lysis [27]. The role of UL18 has been accounted for to hinder the NK-cell (Natural killer cell) mediated lysis in some experimental conditions but not others [28]. Human cytomegalovirus infections are mainly associated with the salivary glands. Cytomegalovirus may be shed in the body fluids like tears, semen, breast milk, saliva, blood and urine of the infected individual. In severe cases, it may cause mucoepidermoid carcinoma and malignancies like prostate cancer. Based on the literature survey [22, 32] the interactions and fitness scores of the complex suggest that this compound can act as an antimicrobial drug against Human cytomegalovirus.

PDB 2 I42 is crystal structure of yersinia protein tyrosine phosphate complexed with vanadate, gene names: yopH yop51

\begin{tabular}{ll}
\hline PDB 2I42 & Energy (kcal/mol) \\
\hline Amino acid residue (predicted pharmacologic interactions) & 0 \\
\hline V-S-ARG-255
\end{tabular}

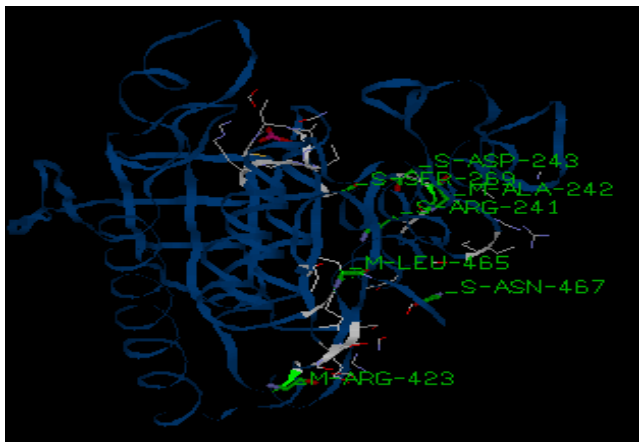

Fig. 7: Docking pose of stannane of pyridoxal 5-phosphate with PDB 2I42

The green and grey colour represent the amino acids involved in(H)hydrogen bonding and(V) van der Waals are interaction types $\mathrm{M}$ and $\mathrm{S}$ are Main chain and the Sidechain.

\section{Interaction profile}

The complex interacted with the PDB file which performs the biological function dephosphorylation that is the process of removing one or more phosphoric (ester or anhydride residue from a molecule, pathogenesis in the host cell and protein tyrosine phosphatase activity that is catalysis of the reaction: Protein tyrosine phosphate (PTP) to protein tyrosine and phosphate. PTP is involved in the regulation of numerous cell functions including growth, differentiation, motility, cell-cell interactions, metabolism, gene transcription, and the immune response of Yersinia enterocolitica. Stannane interacted with total fitness value-84.9563 $\mathrm{kcal} / \mathrm{mol}$ which comprises-70.685 $\mathrm{kcal} / \mathrm{mol}$ van der Waal interactions and-14.2711 kcal/mol hydrogen bonding.

The complex shows the potency to inhibit the growth of Yersinia enterocolitica. It is a causative organism for the disease called 'yersiniosis'. Pathogenic species of Yersinia harbor an extrachromosomal that is crucial for Yersinia pathogenicity. This plasmid encodes the genes of a type III secretion system. On contact with the host cell, the Yersinia has type III secretion system which transfers a set of proteins called Yops (Yersinia outer proteins) into the host cell. YopH, YopE, YopJ/P, YpkA/YopO, YopT, and YopM are the six Yops identified so far, and they inhibit the host immune response during infection $[29,30]$. Five of the six Yops have catalytic activities which are essential for their pathogenic functions [31]. YopH, a protein tyrosine phosphates, constrict the tyrosine phosphorylation signalling that is crucial for the assembly of focal adhesion complexes. Based on the literature survey $[22,32]$ the interactions and fitness scores of the complex suggest that this compound can act as an antimicrobial drug against Yersinia enterocolitica. Thus it could be a potent antibacterial agent for this microbe.

PDB 3E00 is 2.9A crystal structure of methyl-isocitrate lyase from Burkholderia-pseudomallei

\begin{tabular}{ll}
\hline PDB 3EO0 & \\
\hline Amino acid residue (predicted pharmacologic interactions) & Energy (kcal/mol) \\
\hline H-M-ILE-428 & -10.3414 \\
H-M-GLY-429 & -7 \\
V-S-GLU-307 & -6.95152 \\
V-S-LEU-353 & -5.90822 \\
V-M-GLY-429 & -4.9698 \\
\hline
\end{tabular}

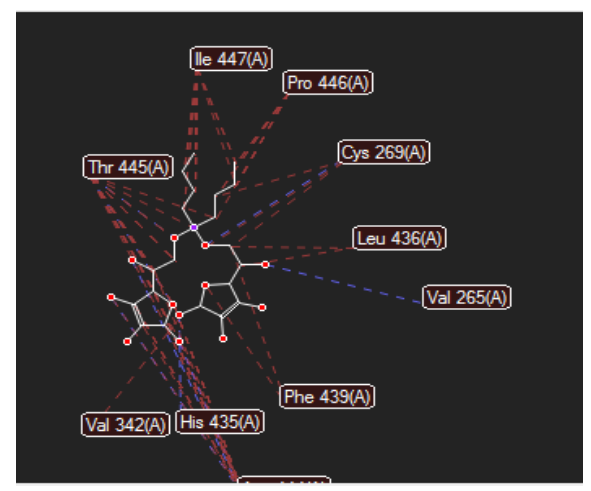

Fig. 8: Docking pose of stannane of pyridoxal 5-phosphate with PDB 3EOO
The green and grey colour represent the amino acids involved in $(\mathrm{H})$ hydrogen bonding and $(\mathrm{V})$ van der Waals are interaction types $\mathrm{M}$ and $\mathrm{S}$ are main chain and the side chain.

Abbreviations: GLY-glycine; ILE-isoleucine; GLU-glutamic acid; LEUleucine.

\section{Interaction profile}

The complex interacted with the PDB file which controls the lyase activity, propionate catabolic process and 2-methylcitrate cycle in the Burkholderia pseudomallei organism, with total fitness value$76.9372 \mathrm{kcal} / \mathrm{mol}$ which comprises van der Waal interaction energy value of-56.226 kcal $/ \mathrm{mol}$, hydrogen bonding with energy value$22.3972 \mathrm{kcal} / \mathrm{mol}$ and electrostatic interaction with energy value $1.68596 \mathrm{kcal} / \mathrm{mol}$. Hydrogen bonding with the main chain of isoleucine at position 428 , glycine at position 429 with binding energy value of- $10.3414 \mathrm{kcal} / \mathrm{mol}$ and-7 kcal/mol respectively. Van 
der Waal interaction with the side chain of glutamic acid at position 307 , leucine at position 353 with binding energy value-6.95152 $\mathrm{kcal} / \mathrm{mol}$ and $-5.90822 \mathrm{kcal} / \mathrm{mol}$ respectively.

The complex has shown binding affinity with this protein; it inhibits the methyl citrate cycle by interacting with methyl-isocitrate lyase. Based on the literature survey [33] the interactions and fitness scores of the complex suggest that this compound can act as an antimicrobial drug by inhibiting the function of the protein. Methylisocitratelyase plays a crucial role as it regulates the methyl citrate cycle [34] in Burkholderia pseudomallei and it is been activated by nicotinamide adenine dinucleotide (NAD) but inhibited noncompetitively by nicotinamide adenine dinucleotid+hydrogen (NADH) and NADPH (nicotinamide adenine dinucleotide phosphate)

\section{CONCLUSION}

Stannane of pyridoxal 5-phosphate was efficiently synthesised and spectroscopically characterised. It was observed in the in vitro antibacterial study, that the complex has shown great potency to be used as an antibacterial agent against Staphylococcus aureus (grampositive) and Escherichia coli 1610 (gram-negative) bacterial strains The complex was found to be more active than the parent ligand pyridoxal 5-phosphate as it has shown no antibacterial activity. Binding results in the in silico study shows that the stannane of pyridoxal 5-phosphate could be a potent inhibitor for the microbes Burkholderia pseudomallei, Human cytomegalovirus, Yersinia enterocolitica and Escherichia coli. The novel complex has shown good antibacterial activity (theoretically) in in silico studies. This study has supported our hypothesis, and these were only the initial biological screening further in vitro studies should be applied to evaluate the biological activity against these microbes, DNA binding studies and anticancer activities; future studies will aim rational design of novel selective and potent inhibitors.

\section{FUNDING}

This research did not receive any specific grant from funding agencies in the public, commercial, or not-for-profit sectors.

\section{ACKNOWLEDGMENT}

The authors would like to thank ARSD College, Delhi University, and Amity University, Noida for their kind support in providing the facilities for successful conduction of this research work.

\section{CONFLICT OF INTERESTS}

Declared none

\section{REFERENCES}

1. Rehman W, Badshah A, Khan S, Tuyet le TA. Synthesis, characterization, antimicrobial and antitumor screening of some di organotin (IV) complexes of 2-[(9H-purin-6-ylimino)]phenol. Eur J Med Chem 2009;44:3981-5.

2. Rehman W, Baloch MK, Badshah A, Ali S. Synthesis, characterization and biological study of di organotin (IV) complexes of monomethyl phthalate. Spectrochim Acta Part A 2006;65:689-94.

3. Akhtar S, Khan MA, Akhtar H, Shahid K. Synthesis, characterization, in vitro antibacterial and antifungal assays of organotin (IV) complexes of nimesulide. Int J Pharm Sci Rev Res 2014;28:106-10.

4. Rahman A, Choudhary MI, Thomsen WJ. Bioassay Techniques for Drug Development, Harwood Academic, Amsterdam. The Netherlands; 2001.

5. Mala Nath, Yadav R, G Eng, Musingarimi P. Characteristic spectral studies and in vitro antimicrobial and in vivo multiinfection antifungal activities in mice of new organotin (IV) derivatives of heterocyclic amino acid. Appl Organomet Chem 1999;13:29-37.

6. Armarego WLF, Perrin DD. 4th edition. Purification of Laboratory Chemicals, Butterworth-Heinemann, Oxford, UK; 1996.

7. Aniyery RB, Gupta A, Singh P, Khatri C, Pathak A. Synthesis, characterization, biological activities and computational anticancer study of Dibutylbis [(2-isopropyl-5-ethylcyclohexyl) oxy] stannane. J Chem Pharm Sci 2015;8:957-63.

8. Basu Baul TS. Antimicrobial activity of organotin (IV) compounds. Appl Organometal Chem 2008;22:195-204.

9. Shete CC, Wadkar S, Inamdar F, Gaikwad N, Patil K. Antibacterial activity of amorphophallus konk anesis and amorphophallus bulbifer tuber. Asian J Pharm Clin Res 2015;8:98-102.

10. Himratul-Aznita $\mathrm{WH}$, Mohd-Al-Faisal $\mathrm{N}$, Fathilah AR Determination of the percentage inhibition of diameter growth (PIDG) of Piper bete lcrude aqueous extract against oral Candida species. J Med Plants Res 2011;5:878-84.

11. Hsu KC, Chen YF, Lin SR, Yang JM. iGEMDOCK: a graphical environment of enhancing GEMDOCK using pharmacological interactions and post-screening analysis. BMC Bioinformatics 2011;12(Suppl 1):S33.

12. Balavignesh V, Srinivasan E, Ramesh Babu NG, Saravanan N. Molecular docking study on NS5B polymerase of hepatitis c virus by a screening of volatile compounds from acacia concinna and ADMET prediction. Int J Pharm Life Sci 2013;4:2548-58.

13. Noel M O'Boyle, Banck M, James CA, Morley C, Vandermeersch T, Hutchison GR. Open babel: an open chemical toolbox. J Chemoinf 2011;3:33

14. Manuela B, Nigel HG, Qian-Sheng Y, A Vincenza. Lipid in health and disease. Scholars Res Library 2009;1216:2730-8.

15. Karpakavalli M, Kumar P, Sanglimuthu A, Kumar EP. Docking, synthesis, characterization and anticancer activity of 4-(4'Hydroxy, 3'-Methoxy) Phenyl, But-2-One-3-Ene, a curcumin analogue precursor. Int J Curr Pharm Res 2016;8:1-5.

16. Sam N, Affan MA, Salam MA, Ahmad FB, Asaruddin MR. Synthesis, spectral characterization and biological activities of organotin (IV) complexes with ortho-vanillin-2hydrazinopyridine (VHP). Open J Inorg Chem 2012;2:22-7.

17. Yeaman MR, Yount NY. Mechanisms of antimicrobial peptide action and resistance. Pharmacol Rev 2003;55:27-55.

18. Basu Baul TS. Antimicrobial activity of organotin (IV) compounds a review. Appl Organometal Chem 2008;22:195-204.

19. Basavaraju B, Bhojya Naik HS, Prabhakara MC. Transition metal complexes of methyl quinoline [3,2-b][1,5]benzodiazepine and methyl quinoline [3,2-b][1,5]benzoxazepine: synthesis, characterrisation, and antimicrobial studies. E-J Chem 2007:4:39-45.

20. Srivastava RS. Pseudotetrahedral Co(II), Ni(II) and Cu(II) complexes of $\mathrm{N}^{1}$-(O-chlorophenyl)-2-(2',4'-dihydroxyphenyl)2-benzylazomethine their fungicidal and herbicidal activity. Inorg Chim Acta 1981;56:65-7.

21. Chohan ZH, Arif M, Muhammad A Akhtar, Supuran CT. Metalbased antibacterial and antifungal agents: synthesis, characterization, and in vitro biological evaluation of Co(II), $\mathrm{Cu}(\mathrm{II}), \mathrm{Ni}(\mathrm{II})$, and $\mathrm{Zn}(\mathrm{II})$ complexes with amino acid-derived compounds. Bioinorg Chem Appl 2006;83131:1-13.

22. Kumar KM, Anitha P, Sivasakthi V, Bag S, Lavanya P, Anbarasu A, et al. In silico study on penicillin derivatives and Cephalosporins for upper respiratory tract bacterial pathogens. 3 Biotech 2014;4:241-51.

23. Kerff F, Petrella S, Mercier F, Sauvage E, Herman R, Pennartz A, et al. Specific structural features of the n-acetylmuramic-l-alanine amidase amid from escherichia coli and mechanistic implications for enzymes of this family. J Mol Biol 2010;397:249-59.

24. Protein Data Bank in Europe. Available from: https://www.ebi.ac.uk/pdbe/entry/pdb/3d2y/biology. [Last accessed on 26 Nov 2016]

25. Protein Data Bank in Europe. Available from: https://www.ebi.ac.uk/pdbe/entry/pdb/3d $2 \mathrm{u}$ [Last accessed on 26 Nov 2016].

26. Beck S, Barrell BG. Human cytomegalovirus encodes a glycoprotein homologous to MHC class-I antigens. Nature 1988;331:269-72.

27. Browne H, Smith G, Beck S, Minson T. A complex between the MHC class I homologue encoded by human cytomegalovirus and beta 2 microglobulins. Nature 1990;347:770-2.

28. Wagner CS, Ljunggren $\mathrm{HG}$, Achour A. Immune modulation by the human cytomegalovirus-encoded molecule UL18, a mystery yet to be solved. J Immunol 2008;180:19-24.

29. Black DS, Bliska JB. Identification of p130Cas as a substrate of Yersinia YopH (Yop51), a bacterial protein tyrosine 
phosphatase that translocates into mammalian cells and targets focal adhesions. EMBO J 1997;16:2730-44.

30. Galán JE, Collmer A. Type III secretion machines: bacterial devices for protein delivery into host cells. Science 1999;284:1322-8

31. Wulff-Strobel CR, Williams AW, Straley SC. LcrQ and SycH function together at the Ysc type III secretion system in Yersinia pestis to impose a hierarchy of secretion. Mol Microbiol 2002;43:411-23.

32. Stuckey JA, Schubert HL, Fauman EB, Zhang ZY, Dixon JE, Saper MA. Crystal structure of Yersinia protein tyrosine phosphatase at

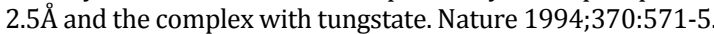

33. Sabbagh G, Murad T. An in silico study of novel fluoroquinolones as inhibitors of DNA gyrase of staphylococcus aureus. Int J Pharm Pharm Sci 2016;8:67-75.

34. Upton AM, McKinney JD. The role of the methyl citrate cycle in propionate metabolism and detoxification in mycobacterium smegmatis. Microbiology 2007;153:3973-82.

\section{How to cite this article}

- $\quad$ Rohit Babu Aniyery, Anita Gupta, Prashant Singh, Sanju. In vitro and in silico antimicrobial study of stannane of pyridoxal 5phosphate. Int J Pharm Pharm Sci 2017;9(2):145-153. 